\title{
An isotopically enriched mantle component in the source of Rodrigues, Réunion volcanic hotspot
}

\author{
MARC C. HALFAR ${ }^{1}$, BRADLEY PETERS ${ }^{1}$, JAMES M. D. \\ DAY $^{2}$ AND MARIA SCHÖNBÄCHLER ${ }^{1}$ \\ ${ }^{1}$ ETH Zürich \\ ${ }^{2}$ Scripps Institution of Oceanography \\ Presenting Author: marc.halfar@erdw.ethz.ch
}

The Mascarene Islands in the western Indian Ocean, encompassing La Réunion, Mauritius and Rodrigues, provide one of Earth's most pristine records of its deep interior and primordial history. Ocean island basalts (OIB) from these islands, which sample the Réunion hotspot, exhibit a remarkably limited range in isotopic compositions that generally overlap the focal zone (FOZO) in the mantle array. Besides this signature, Mascarene lavas may preserve influences from sources with distinct compositions, including: (1) shallow continental crust preserved by Archaean-aged zircons in Mauritian trachytes; (2) deeper continental crust components preserved by slightly elevated ${ }^{87} \mathrm{Sr} /{ }^{86} \mathrm{Sr}$ and ${ }^{208} \mathrm{~Pb} /{ }^{206} \mathrm{~Pb}$ ratios in lavas from the Piton des Neiges volcano on La Réunion; and (3) an isotopically depleted component resulting from migration of Central Indian Ridge (CIR) material.

We use major and trace element compositions, as well as new $\mathrm{Sr}$ and $\mathrm{Pb}$ isotope data of basaltic lavas from all three Mascarene Islands to investigate their mantle sources in terms of their relationship to well-characterized mantle endmember compositions. The trace element data reveals distinct patterns for each island. Rodrigues lavas are the most enriched in the highly incompatible trace elements, which likely reflects a lower degree of partial melting. Combined $\mathrm{Pb}-\mathrm{Sr}$ isotopic compositions indicate that Mauritian Older Series lavas have a stronger Réunion-type component, while those from the Mauritian Younger and Intermediate Series, along with Rodrigues, display a contribution of a more depleted component.

Lead isotopes further suggest the contribution of an enriched component in the Rodrigues basalts. Isotope mixing models reveal that the $\mathrm{Pb}$ isotopic signature of Rodrigues rocks is inconsistent with direct assimilation of shallow continental crust. Instead, a distinct enriched component, either with a Pitcairn-like EM-1, or a "fossil" Réunion plume contribution, was determined as a best fit for a required enriched source in these models. While the combined $\mathrm{Sr}-\mathrm{Pb}$ isotopic compositions require an EM-1 component contribution of only $<2 \%$ to explain the Rodrigues samples, a much larger $(>60 \%)$ proportion of a "fossil" plume component would be necessary. Such a component may be a new feature of OIB from the Mascarene Islands and is only observed for Rodrigues OIB. 